УДК 341.16:001UNESC0:37.046«20»:043.86

DOI: https://doi.org/10.35387/ucj.1(1).2020.8-11

HALYNA SOTSKA

\title{
UNESCO CHAIR ON LIFELONG PROFESSIONAL EDUCATION IN THE XXI CENTURY OF THE NAES OF UKRAINE: STRATEGIC DIRECTIONS OF DEVELOPMENT
}

\begin{abstract}
The article outlines the strategic goal of the UNESCO Chair on Lifelong Professional Education in the XXI Century of the National Academy of Educational Sciences of Ukraine. The main tasks of the Chair are as follows: to promote the creation of an educational platform for the exchange of knowledge and best practices by organizing and conducting events, creating a database and a special web site, preparing and distributing publications, including online; consolidation of the community of teachers, researchers and students in the field of professional and pedagogical education as well as adult education; dissemination of knowledge and support in the development and implementation of national strategies and plans for professional training and adult education throughout life; to establish cooperation with other UNESCO Chairs within the framework of corresponding programs and activities. The information on the organization and holding by the Chair of scientific and practical mass events aimed at the development of international academic and scientific solidarity (webinar "Mother language and multilingual education in the context of sustainable development", round table "T.H. Shevchenko's Civic and Patriotic Ideas in the Socio-Cultural and Educational Space of Ukraine", the scientific-practical conference "Museum Pedagogy: Problems, Present, Prospects", etc.) has been revealed. This contributed to the intensification of the knowledge exchange among the world's universities, strengthening inter-chair coordination, increasing network collaboration, expanding partnerships and setting up joint platforms for interdisciplinary dialogue with the support of the UNITWIN / Chair Coordinating Board in Ukraine. The prospects for further activity of the Chair are determined, in particular: expansion of cooperation with international and national experts in the spheres of education, science and culture; assistance to staff and graduate students of the Institute in obtaining grants for educational, research and cultural projects; strengthening of educational and cultural initiatives in adult education; conducting events aimed at raising the level of quality of scientific and pedagogical staff training by increasing the number of international projects with foreign partners, within which staff, graduate students and doctoral students of the Institute will have the opportunity to undergo study / internship in foreign educational institutions through academic mobility programs.
\end{abstract}

Key words: UNESCO, UNESCO Chair, National Academy of Educational Sciences of Ukraine, lifelong professional education of the XXI century, strategy, network interaction.

\section{КАФЕДРА ЮНЕСКО «НЕПЕРЕРВНА ПРОФЕСІЙНА ОСВІТА ХХІ СТОЛІТТЯ» НАПН УКРАЇНИ: СТРАТЕГІЧНІ НАПРЯМИ РОЗВИТКУ}

Анотація. У статті розкрито стратегічну мету діяльності кафедри ЮНЕСКО «Неперервна професійна освіта ХХІ століття» НАПН України. Окреслено основні завдання Кафедри: сприяння створенню освітньої платформи для обміну знаннями й кращими взірцями практичного досвіду шляхом організації та проведення заходів, створення бази даних та спеціального веб-сайту, підготовка й поширення публікацій, у тому числі онлайн; консолідація спільноти викладачів, дослідників і студентів у галузі професійно-педагогічної освіти і освіти дорослих; поширення знань $і$ надання підтримки в розробленні й імплементації національних стратегій і планів щодо професійної підготовки, а також освіти дорослих упродовж життя; налагодження співпраці з іншими кафедрами ЮНЕСКО в межах відповідних програм і заходів. Висвітлено інформацію про організацію та проведення Кафедрою науково-практичних масових заходів з метою розвитку міжнародної академічної та наукової солідарності (вебінар «Рідномовна і багатомовна освіта у контексті сталого розвитку», круглий стіл «Громадянсько-патріотичні ідеї Т.Г. Шевченка в соціокультурному та освітньому просторі України», науково-практична конференція «Музейна педагогіка: проблеми, сьогодення, перспективи» тощо). Це сприяло інтенсифікації обміну знанням між університетами світу, посиленню міжкафедральної координації, підвищенню рівня мережевого співробітництва, розширенню партнерських зв'язків і створенню спільних майданчиків для міждисциплінарного діалогу за підтримки Координаційної ради Програми «UNITWIN/кафедри» в Україні. Визначено перспективи подальшої діяльності Кафедри, зокрема: розширення співпраці з міжнародними й національними експертами в галузях освіти, науки й культури; сприяння співробітникам і аспірантам Інституту в отриманні грантів на освітні, науково-дослідні й культурологічні проекти; посилення освітньо- 
культурних ініціатив в освіті дорослих; проведення заходів з метою підвищення рівня якості підготовки науково-педагогічних працівників шляхом збільшення кількості міжнародних проектів із закордонними партнерами, в межах яких співробітники, аспіранти та докторанти Інституту матимуть можливість пройти навчання / стажування у зарубіжних закладах освіти за програмами академічної мобільності.

Ключові слова: ЮНЕСКО, Кафедра ЮНЕСКО, Національна академія педагогічних наук України, неперервна професійна освіта ХХІ століття, стратегія, мережева взаємодія.

Introduction. In modern globalized society, an important aspect is cooperation between UNESCO and Ukraine. UNESCO is an international intergovernmental organization that has been officially in existence since November 4, 1946. According to the Statement, UNESCO's main objective is to promote peace and security by enhancing cooperation between peoples in the fields of education, science and culture, as well as the need to protect peace in the minds of the people.

The main areas of competence of UNESCO are: education (from pre-school to higher and lifelong; adult education, preventive, special, vocational and environmental); natural sciences and humanities; culture and international cultural cooperation; media, informatics and communication. Accordingly, UNESCO's mission is to strengthen the intellectual and moral solidarity of humankind, and thus to create the humanitarian foundations of a comprehensive system of international security and stability.

Results. In October 25, 2016 has been signed the Agreement between UNESCO (UNESCO Director-General Irina Bokova) and the National Academy of Educational Sciences of Ukraine (hereinafter - NAES of Ukraine; President of the National Academy of Educational Sciences of Ukraine Vasyl Kremen). According this Agreement has been established UNESCO Chair on Lifelong Professional Education of the XXI Century that based at the Institute of Pedagogical and Adult Education of the National Academy of Educational Sciences of Ukraine.

The strategic goal of the UNESCO Chair in cooperation with fields institutions of higher education, scientific institutions, public organizations should overcome contradictions between the problem of national and international research, between the fundamental and practical achievements of scientists, between the generation of new abstract ideas and the production of utilities knowledge, between science as a driving force for commercial activity (UNESCO Report on Science: Towards to 2030, 2015a).

The UNESCO Chair activities is governed by UNESCO regulations, in particular: "Incheon Declaration. Education - 2030: Ensuring univer- sal inclusive and equitable quality education and lifelong learning"(Republic of Korea, World Education Forum, 2015), "UNESCO Report on Science: Towards to 2030”(2015b), “Rethinking Education: Education as a common good'(2015c), World Monitoring Report "Education for All"(2015), "The Muscat Agreement "(Global Council on Program "Education for All", 2014), "Guidelines and Recommendations for Teacher Education Reorientation as sustainable development'(2005), etc.

The conceptual idea of UNESCO in the field of education is specified in the UNESCO Strategy Paper "Rethinking Education: Education as a Common Good" (2015), which proclaimed that education is a key aspect of global complex problems that determine goals of sustainable development, in particular for the adaptation of society, individual states, of nations to social change, transforming the world, realizing education as the basis of lifelong learning in a complex and fastchanging world

This conceptual idea has been highlighted in the specific objectives of UNESCO Chair, such as: develop, jointly with partners, new programmes at the undergraduate and postgraduate levels for the training and retraining of scientific and pedagogical personnel and for adult lifelong learning, as well as to provide training; promote networking and the sharing of knowledge and good practices, notably through the organization of events, the creation of a data base and dedicated website, and the production and dissemination or publications, including online; foster the establishment of a network of institutions, faculty, researchers and students in the field of professional and pedagogical education and adult education; contribute knowledge and support for the development and implementation of national strategies and plans for the training and professional development of teachers, as well as for adult lifelong learning; and, cooperate closely with UNESCO on relevant programmes and activities, as well as with other relevant UNESCO Chairs.

In accordance with the strategic goals of the UNESCO Medium-Term Strategy Program 2014-2021 (General Conference Resolution 37 $\mathrm{C} / 4$ ), the priorities UNESCO Chair activities are 
consistent with the Major Programs I - "Education"; III "Social Sciences and Humanities" and "Culture". Accordingly, the main areas of activity of these programs are: I - "Member States' support for the achievement of the Sustainable Development Goals 4 (SDG) - "Education 2030"; III - "Promoting intercultural dialogue and involving young people in building peaceful and open societies" and IV - "Culture" - "Encouraging creativity and diversity of cultural expressions, as well as safeguarding intangible cultural heritage for the sake of ensuring sustainable development".

In Ukraine has held scientific and practical events (international conferences, seminars, round tables, trainings, co workings, etc.) to developing international academic solidarity and intensifying knowledge sharing between universities in different countries, enhancing inter-Chair coordination, enhancing networking, expanding partnerships, and creating joint platforms for interdisciplinary dialogue with the support of the UNITWIN Program Coordination Council.

UNESCO Chair on Lifelong Professional Education in the XXI Century of the National Academy of Educational Sciences of Ukraine is the only institution from Ukraine that has participated in the thematic events and presented on the international online platform "International Indigenous Languages Year 2019". UNESCO Chair in cooperation with the Taras Shevchenko All-Ukrainian Society "Prosvita", The Congress of the Ukrainian Intellectuals, The Hrinchenko Research Laboratory of Boris Hrinchenko Kyiv University, The Research Laboratory of Scientist Academic Culture of the Anton Makarenko Sumy State University annually has been hosted a webinar, "Mother tongue and Multilingual Education in the Context of Sustainable Development", dedicated to International Mother Language Day, which was proclaimed by Bangladesh and approved by the UNESCO General Conference in 1999.

The aim of event - spread of education in the context of global citizenship, saving linguistic diversity and promoting multilingualism. This aim has been highlighted in the UNESCO Education Framework - 2030. The webinar helps to increase the dialogic interaction between scientists, educators, and public figures; affirming the priorities of cultural responsibility and multiculturalism in the modern world.

In order to maintain the status of the Ukrainian language as a state language and priority of civic values in the education of Ukraine; aware- ness the language role of other nationalities and the language of indigenous peoples in modern Ukraine has been held annually round table "Civic and Patriotic Ideas of Taras Shevchenko in the socio-cultural and educational space of Ukraine".

Two events of the UNESCO Chair: the annual webinar "Mother tongue and multilingual education in the context of sustainable development" and the round table "Civic and patriotic ideas of Taras Shevchenko in the socio-cultural and educational space of Ukraine" has been presented on the international stage. At the end of 2019, the UN General Assembly has presented a report by the Special Rapporteur on Indigenous Rights on the participation of various countries all over the world in the International Indigenous Languages Year 2019.

A good tradition of the UNESCO Chair to participate in the organization and holding of the Annual Conference "Museum Pedagogy: Problems, Presentities, Prospects" in cooperation with the Ukrainian Adult Education Association and National Kyiv-Pechersk Historical and Cultural Reserve. The purpose of the event is to exchange information and pedagogical experience on the problem of museum pedagogy in the context of lifelong education; socio-cultural dimension of museum communication; historical and cultural heritage and use of its potential in the spiritual development of the individual; innovative forms and methods of museum pedagogy in dealing with different target audiences; promoting UNESCO's ideas in the fields of culture, art and education. This is in line with the goals of the "Roadmap on Art Education" (Lisbon, 2006), the UNESCO Program on Sustainable Development of Art Education to Promote Diversity of Cultural Expressions (2009), and the UNESCO Declaration on Cultural Diversity (Paris, 2001).

The activity of the UNESCO Chair is directed on strengthening role of adult education as an important factor of social progress, competitiveness of the state, creation of conditions for selfdevelopment and self-realization of the individual in the context of the concept "lifelong education".

The results of the UNESCO Chair activities are systematically highlighted in mass media; in all-Ukrainian and regional press; on the pages of scientific publications and on the official website of the UNESCO Chair http://ipood.com.ua/unesco/. The members of UNESCO Chair take an active part in Meetings of the National Commission of Ukraine on UNESCO and international scientific and practical events. In particular, October 25- 
27, 2017, UNESCO Chair has been participated in the Expert Committee of the Medium-Term Review on "Life and Learning for a Viable Future: looking to 2030" according to the Sixth UNESCO International Intergovernmental Conference on Adult Education and Training in Suwon (South Korea). There have been presented the scientists research achievements of the Ivan Ziaziun Institute of Pedagogical and Adult Education and UNESCO Chair on Lifelong Professional Education of the XXI Century.

Conclusions. Among the socially important functions of the UNESCO Chair in the educational and scientific space of Ukraine is to promote the national identity of the pedagogical elite, different categories of adults, forming in them a sense of belonging to the cultural and political society at the state level, community, region, readiness to participate in social life. All these aspects has connected with responsibility, professionalism, civic-minded outlook, ability to innovate, etc. ("Rethinking Education: Education as General Good (2015)).

Further work of the UNESCO Chair will be directed to realization of the basic tasks of scien- tific, cultural and innovative activity of the $\mathrm{Na}$ tional Academy of Educational Sciences of Ukraine. Main directions of the UNESCO Chair activities include: expansion of cooperation with international and national experts in the fields of education, science and culture; assisting the Institute's research staff and graduate students in obtaining grants for educational, research and cultural projects; enhancing educational and cultural initiatives in adult education. These activities will be continued to improve the quality of teacher training staff, as well as to increase the number of international projects with foreign partners, in which research staff, graduate students and doctoral students of the Institute will have the opportunity to undergo training / internships in foreign educational institutions on mobility programs.

The UNESCO Chair on Lifelong Professional Education of the XXI Century is open to cooperation with other UNESCO Regional Chairs, educational and scientific institutions, international organizations in the field of lifelong education.

\section{REFERENCES}

UNESCO. (2005). Guidelines and recommendations for reorienting teacher education to address sustainability. URL: https://unesdoc.unesco.org/ark:/48223/pf0000143370

UNESCO. (2014). Global Education for All Meeting UNESCO, Muscat, Oman 12 - 14 May 2014. URL: http://www.unesco.org/new/fileadmin/MULTIMEDIA/FIELD/Santiago/pdf/Muscat-AgreementENG.pdf

UNESCO. (2015a). UNESCO Science Report: towards 2030. URL: http://uis.unesco.org/sites/ default/files/documents/unesco-science-report-towards-2030-part1.pdf

UNESCO. (2015b). Education 2030 - Incheon Declaration - Towards inclusive and equitable quality education and lifelong learning for all. URL: https://reliefweb.int/sites/reliefweb.int/files/resources/FFA Complet Web-ENG.pdf

UNESCO. (2015c). Global Education Monitoring Report. URL: https://en.unesco.org/gemreport/taxonomy/term/199

Галина Сотська, доктор педагогічних наук, професор, член-кореспондент НАПН України, заступник директора 3 науково-експериментальної роботи Інституту педагогічної освіти і освіти дорослих імені Івана Зязюна НАПН України, керівник кафедри ЮНЕСКО «Неперервна професійна освіта XXI століття».

Halyna Sotska, Doctor of Sciences in Pedagogy, Professor, Corresponding Member of the NAES of Ukraine, Vice-director on scientific and experimental work at the Ivan Ziaziun Institute of Pedagogical and Adult Education of the NAES of Ukraine, The Head of UNESCO Chair on Lifelong Professional Education in the XXI Century.

E-mail: galasotska@ukr.net ORCID ID 0000-0002-0184-2715 